\section{Shiga-toxigenic Escherichia coli in ready-to-eat food staffs: Prevalence and distribution of putative virulence factors}

\author{
Mohammad Hossein Sakhaie Shahreza, ${ }^{1}$ \\ Ebrahim Rahimi, ${ }^{2}$ Hassan Momtaz ${ }^{3}$ \\ ${ }^{1}$ Department of Student of Veterinary \\ Medicine, College of Veterinary \\ Medicine; ${ }^{2}$ Department of Food Hygiene \\ and Public Health, College of Veterinary \\ Medicine; ${ }^{3}$ Department of Microbiology, \\ College of Basic Sciences, Shahrekord \\ Branch, Islamic Azad University, \\ Shahrekord, Iran
}

\begin{abstract}
Lack of proper hygiene and using from low quality raw materials cause high presence of food-borne pathogens in ready to eat foods. Shiga toxin producing Escherichia coli is one of the most common cause of food-borne diseases in the world. The present research was done to study the prevalence and distribution of virulence factors in the STEC strains isolated from various types of ready to eat food samples. Seven-hundred and twenty food samples were collected and cultured. Isolated $E$. coli bacteria were approved another time using the $16 S$ rRNA-based PCR amplification. Approved strains were subjected to multiplex PCR for identification of putative virulence factors. Twenty-six out of 720 food samples $(5.20 \%)$ were positive for $E$. coli. Salad (15\%), candy (12.50\%) and barbecue $(10 \%)$ were the most commonly contaminated. Prevalence of STEC strains was $2.63 \%$. Prevalence of EHEC and AEEC subtypes were $36.84 \%$ and $52.63 \%$, respectively. EHEC strains harbored all three stx1, eae and ehly genes. High presence of EHEC strains besides the considerable distribution of multiple virulence factors showed an important public health issue regarding the consumption of ready to eat foods.
\end{abstract}

\section{Introduction}

Food hygiene in restaurants and fastfoods are one of the most important critical issue. Using from low quality raw materials, cooking of foods more than daily requirement and their storage in unsuitable conditions and finally lack of the proper hygiene are the main factors causing enhancement of the microbial spoilage and growth of dangerous food-borne pathogens in foods. ${ }^{1}$ Among all pathogenic agents causing food-borne diseases, Escherichia coli $(E$. coli) strains had a significant position. ${ }^{2-8}$ E. coli is a Gram-negative, non-sporulating, flagellated, rod-shaped and facultative anaerobic bacterium of the Enterobacteriaceae family. Shiga (vero) toxin (Stx)-producing E. coli (STEC) is a subdivision of a significant pathogenic group of this bacterium named enterohemorrhagic E. coli (EHEC). ${ }^{2-8}$ In the other hand, STEC strains are divided into two separate subtypes of EHEC and Attaching and Effacing E. coli (AEEC). EHEC strains are responsible for high morbidity and mortality. AEEC strains are described by their ability to occur attachingand-effacing $(\mathrm{A} / \mathrm{E})$ lesions in the gastrointestinal tract of humans and animals. ${ }^{2-8}$ STEC bacteria are responsible for severe clinical syndromes like Hemorrhagic Colitis (HC), Hemolytic Uremic Syndrome (HUS), bloody and non-bloody diarrhea and Thrombotic Thrombocytopenic Purpura (TTP). ${ }^{2-8}$

Presence of latent virulence factors including Shiga toxins (stx1 and stx2), intimin $(e a e A)$ and hemolysin $(h l y A)$ in the STEC strains of food products make them dangerous pathogens for human health. These genes are responsible for bacterial adhesion, colonization and invasion into the gastric epithelial cells. ${ }^{2-8}$

According to the uncertain role of STEC strains in ready to eat foods and lack of epidemiological and microbiological investigations in this field in Iran, the present research was done to study the prevalence and distribution of virulence factors in the STEC strains isolated from various types of ready to eat food samples.

\section{Materials and Methods}

\section{Ethical considerations}

The research was permitted by the Ethical Board of Islamic Azad University, Shahrekjord Branch (Consent Ref Number IAU 2053). Confirmation of this project and the authorizations related to sampling process were given by the Prof. Ebrahim Rahimi (Approval Ref Number FoodHygiene 952020).

\section{Samples and Escherichia coli isolation}

From September 2013 to September 2014 , a total of 720 various types of readyto-eat foods including sausage $(n=70)$, salami $(n=70)$, hamburger $(n=60)$, roast mouthful $(n=60)$, traditional dressing $(n=65)$, traditional salad $(n=60)$, traditional candy
Correspondence: Ebrahim Rahimi, Full Professor of Food Hygiene and Public Health, Faculty of Veterinary Medicine, Shahrekord Branch, Islamic Azad University, Shahrekord, Iran.

Tel.:+98.9133.278377.

E-mail: ebrahimrahimi55@yahoo.com

Key words: Shiga toxin producing Escherichia coli, Virulence factors, Ready to eat foods, Iran.

Acknowledgements: The authors would like to thank Prof. Amir Shakerian at the Department of Food Hygiene, Shahrekord Branch, Isamic Azad University, Shahrekord, Iran for his important technical support. This work was supported by the Islamic Azad University, Shahrekjord Branch (Ref Number IAU-Bud-177)

Contributions: the authors contributed equally.

Conflict of interest: the authors declare no potential conflict of interest.

Received for publication: 26 May 2017.

Revision received: 29 May 2017.

Accepted for publication: 5 June 2017.

This work is licensed under a Creative Commons Attribution NonCommercial 4.0 License (CC BY-NC 4.0).

(C) Copyright M.H. Sakhaie Shahreza et al., 2017 Licensee PAGEPress, Italy

Microbiology Research 2017; 8:7244

doi:10.4081/mr.2017.7244

$(n=60)$, traditional ice-cream $(n=60)$, barbecue $(n=70)$, soup $(n=75)$ and spices $(n=70)$ were randomly collected from various restaurants in the Isfahan province, Iran. Samples were immediately transferred to laboratory in cooler with ice-packs.

Totally, $10-\mathrm{g}$ of crushed food samples were homogenized for $2 \mathrm{~min}$ in $90 \mathrm{~mL}$ of Peptone Water (PW, Merck, Germany). Then the samples were cultured on 5\% sheep blood and MacConkey agar (Merck, Germany) and incubated for 18 to $24 \mathrm{~h}$ at $37^{\circ} \mathrm{C}$. Colonies with the typical color and appearance of $E$. coli were picked and streaked again on blood agar plates and restreaked on EMB agar (Merck, Germany). All plates were further incubated for $24 \mathrm{~h}$ at $37^{\circ} \mathrm{C}$. The green metallic colonies were considered as E. coli. The presumptive colonies were biochemically tested for growth on triple sugar iron agar (TSI) and lysine iron agar (LIA), oxidative/fermentative degradation of glucose, citrate utilization, urease production, indol fermentation, tryptophan degradation, glucose degrada- 
tion (methyl red test) and motility. Bacterial strains were sub-cultured overnight in Luria-Bertani broth (Merck, Germany) and further incubated for $48 \mathrm{~h}$ at $37^{\circ} \mathrm{C}$. Genomic DNA was extracted from bacterial colonies using the DNA extraction kit (Fermentas, Germany) according to manufacturer's instruction. Bacterial colonies were further confirmed using the $16 S$ rRNA-based Polymerase Chain Reaction (PCR). ${ }^{9}$ Set of primers used for this purpose were Forward: 5'-AGTTTGATCCTGGCTCAG3' and Reverse: 5'-AGGCCCGGGAACGTATTCAC-3' (1343 bp).

\section{PCR amplification of virulence factors}

Table 1 shows the list of primers and PCR program used for detection of virulence factors. ${ }^{6-8}$ Programmable DNA thermo-cycler (Eppendorf Flexrcycler ${ }^{2}$, Germany) was used in all PCR reactions. Those strains which were simultaneously positive for all stxl, eaeA and ehly genes were considered as EHEC subtype. ${ }^{6-8}$ Others which were positive for stx 1 , stx 2 and $e a e A$ genes were considered as AEEC subtype. ${ }^{6-8}$ A multiplex PCR reaction was done in a final volume of $50 \mu \mathrm{L}$. Volume of each material is presented in Table 1 . The PCR amplification products $(15 \mu \mathrm{L})$ were subjected to electrophoresis in a $1.5 \%$ agarose gel in $1 \mathrm{X}$ TBE buffer at $80 \mathrm{~V}$ for 30 min, stained with SYBR Green (Fermentas, Germany). All runs included a negative DNA control consisting of PCR grade water and strains of E. coli O157:K88ac:H19, CAPM 5933 and E. coli O159:H20, CAPM 6006 were used as positive controls.

\section{Statistical analysis}

Statistical analysis was performed using SPSS/16.0 software for significant relation- ships. The prevalence of virulence factors in the E. coli strains isolated from various types of ready to eat food samples were statistically analyzed. Statistical significance was regarded at a $\mathrm{P}$ value $<0.05$.

\section{Results}

Table 2 indicates the prevalence of $E$. coli in various types of ready to eat food samples. Twenty-six out of $720(5.20 \%)$ food samples were positive for $E$. coli. There were no positive results for sausage,

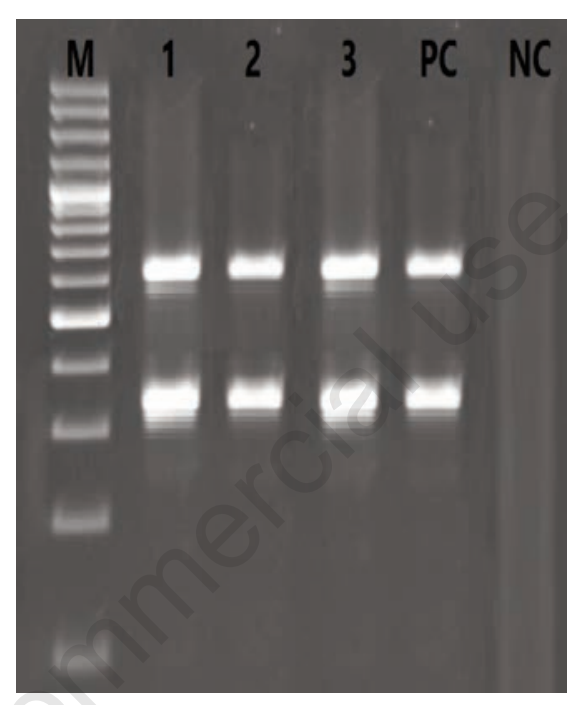

Figure 1. Results of the gel electrophoresis for virulence factors. M: $100 \mathrm{bp}$ ladder, 13: Positive samples for stx1 (366 bp) and eaeA (629 bp) genes, PC: Positive control and NC: Negative control. salami, roast mouthful and soup samples. Salad (15\%), candy (12.50\%) and barbecue (10\%) had the highest prevalence of $E$. coli. Statistically significant differences were seen between the types of samples and prevalence of E. coli $(\mathrm{P}<0.05)$.

Figures 1 and 2 represent the results of the gel electrophoresis for $s t x 1$, eaeA and also stx 2 and ehly virulence factors, respectively. Table 3 represents the distribution of virulence factors in the $E$. coli strains isolated from various types of ready to eat food samples. We found that 19 out of $26 \mathrm{E}$. coli strains $(73.07 \%)$ had Shiga toxigenic virulence factors and were determined as STEC

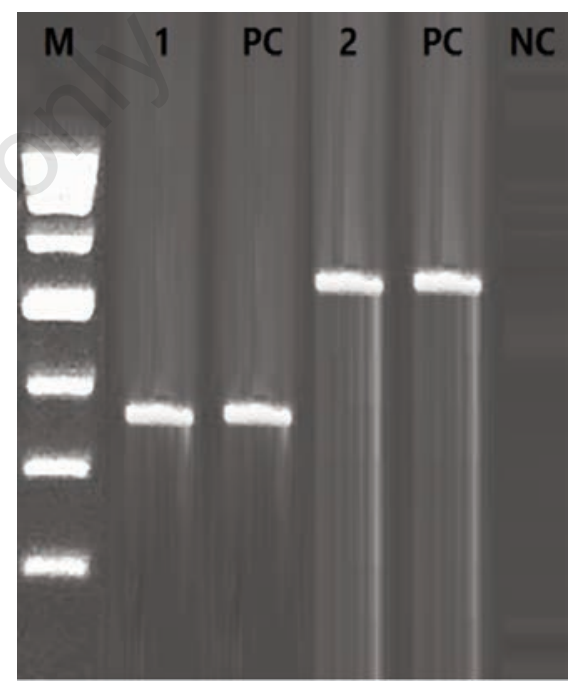

Figure 2. Results of the gel electrophoresis for virulence factors. M: 100 bp ladder, 1 : Positive sample for $s t \times 2$ gene (282 bp), 2: Positive sample for ebly gene (432 bp), PC: Positive controls and NC: Negative control.

Table 1. Oligonucleotide primers and the PCR program used for amplification of virulence factors in the Escherichia coli isolates of ready to eat foods. ${ }^{6-8}$

\begin{tabular}{|c|c|c|c|c|}
\hline Target gene & Primer sequence $\left(5^{\prime}-3^{\prime}\right)$ & PCR product (bp) & PCR programs & PCR volume (50 $\mu \mathrm{L})$ \\
\hline stxl & $\begin{array}{c}\text { F: AAATCGCCATTCGTTGACTACTTCT } \\
\text { R: TGCCATTCTGGCAACTCGCGATGCA }\end{array}$ & 366 & $\begin{array}{c}1 \text { cycle: } 95^{\circ} \mathrm{C}-3 \text { min. } \\
34 \text { cycle: } \\
94^{\circ} \mathrm{C}-60 \mathrm{~s} \\
56^{\circ} \mathrm{C}-45 \mathrm{~s} \\
72^{\circ} \mathrm{C}-60 \mathrm{~s} \\
1 \text { cycle: } 72^{\circ} \mathrm{C}-10 \mathrm{~min}\end{array}$ & $\begin{array}{c}5 \mu \mathrm{L} \text { PCR buffer 10X; } \\
2 \mathrm{mM} \text { Mgcl2; } \\
150 \mu \mathrm{M} \text { dNTP (Fermentas); } \\
0.75 \mu \mathrm{M} \text { of each primers F\&R; } \\
1.5 \text { U Taq DNA polymerase (Fermentas); } \\
3 \mu \mathrm{L} \text { DNA template }\end{array}$ \\
\hline
\end{tabular}

stx2 2 : CGATCGTCACTCACTGGTTTCATCA
R: GGATATTCTCCCCACTCTGACACC
eaeA $\quad$ F: TGCGGCACAACAGGCGGCGA
R: CGGTCGCCGCACCAGGATTC
F29
F: CAATGCAGATGCAGATACCG
R: CAGAGATGTCGTTGCAGCAG


strains. Total prevalence of STEC strains in various types of food samples were $2.63 \%$. Results showed that the prevalence of EHEC and AEEC subtypes in the E. coli strains of ready to eat food samples were $36.84 \%$ and $52.63 \%$, respectively. EHEC strains harbored all three stxl, eae and ehly genes. Statistically significant difference was seen between the prevalence of EHEC and AEEC subtypes $(\mathrm{P}<0.05)$.

\section{Discussion}

The present research showed that virulent STEC strains had a significant prevalence in various types of ready to eat food samples and especially Salad, candy and barbecue. We found that the prevalence of $E$. coli strains and also STEC strains in various types of ready to eat foods were $5.20 \%$ and $2.63 \%$, respectively. Using from low quality and contaminated raw materials, application of contaminated dishes and equipment used for food preparation and finally lack of adequate time and temperature for well cooking of foods are the most important reasons for the high prevalence of
E. coli and STEC strains in our study. However, the role of infected staffs as a sources of STEC strains could not be ignore.

The main source of human EHEC and AEEC contaminations are contaminated

Table 2. Prevalence of Escherichia coli strains in various types of ready to eat food samples.

\begin{tabular}{lccc} 
Types of samples & $\begin{array}{c}\text { N. samples } \\
\text { collected }\end{array}$ & $\begin{array}{c}\text { N. positive } \\
\text { strains (\%) }\end{array}$ & $\begin{array}{c}\text { PCR } \\
\text { confirmation (\%) }\end{array}$ \\
Sausage & 70 & - & - \\
Salami & 70 & - & - \\
\hline Hamburger & 60 & $1(2.50)$ & $1(2.50)$ \\
Roast mouthful & 60 & - & - \\
\hline Dressing & 65 & $4(8)$ & $4(8)$ \\
Salad & 60 & $6(15)$ & $6(15)$ \\
\hline Candy & 60 & $5(12.50)$ & $2(12.50)$ \\
Ice cream & 60 & $2(5)$ & $5(10)$ \\
\hline Barbecue & 70 & $5(10)$ & - \\
Soup & 75 & - & $3(5)$ \\
Spices & 70 & $26(5.20)$ & $26(5.20)$ \\
Total & 720 & &
\end{tabular}

and undercooked ready to eat foods and especially foods with animal origin like raw and under-cooked meat. ${ }^{9-12}$ All of the ready to eat food samples of our investigation were meat-based ready to eat foods. Some of them like sausage, salami and soup were

Table 3. Distribution of virulence factors and subtypes in the Escherichia coli strains isolated from ready to eat food samples.

\begin{tabular}{|c|c|c|c|}
\hline \multicolumn{2}{|c|}{ Samples (positive) } & \multirow{2}{*}{$\begin{array}{l}\text { Subtypes } \\
- \\
1(100) \\
- \\
1(100)\end{array}$} & \multirow{2}{*}{$\begin{array}{l}\text { N. positive samples Virulence genes } \\
\text { - } \\
\text { stx1, eae, ehly: } 1 \text { (100) } \\
\text { stxl: 0; stx2: 0; eaeA: 0; stx1, eaeA: 0; stx2, eaeA: 0; stx1, stx2, eaeA: } 0\end{array}$} \\
\hline Hamburger (1) & $\begin{array}{l}\text { Non detected } \\
\text { EHEC } \\
\text { AEEC } \\
\text { Total }\end{array}$ & & \\
\hline Dressing (4) & $\begin{array}{l}\text { Non detected } \\
\text { EHEC } \\
\text { AEEC } \\
\text { Total }\end{array}$ & $\begin{array}{l}1(33.33) \\
2(66.66) \\
3(75)\end{array}$ & $\begin{array}{l}\text { stxl, eae, ehly: } 1 \text { (100) } \\
\text { stxl: } 2 \text { (100); stx2: } 1 \text { (50); eaeA: } 2 \text { (100); stxl, eaeA: } 1 \text { (50); stx2, eaeA: } 1 \text { (50); stxl, stx2, eaeA: } 1 \text { (50) }\end{array}$ \\
\hline Salad (6) & $\begin{array}{l}\text { Non detected } \\
\text { EHEC } \\
\text { AEEC } \\
\text { Total }\end{array}$ & $\begin{array}{l}1(25) \\
1(25) \\
2(50) \\
4(66.66)\end{array}$ & $\begin{array}{l}\text { stxl, eae, ehly: } 1 \text { (100) } \\
\text { stxl: } 2 \text { (100); stx2: } 1 \text { (50); eaeA: } 2 \text { (100); stxl, eaeA: } 1 \text { (50); stx2, eaeA: } 1 \text { (50); stx1, stx2, eaeA: } 1 \text { (50) }\end{array}$ \\
\hline Candy (5) & $\begin{array}{l}\text { Non detected } \\
\text { EHEC } \\
\text { AEEC } \\
\text { Total }\end{array}$ & $\begin{array}{l}2(50) \\
1(25) \\
2(50) \\
4(80)\end{array}$ & $\begin{array}{l}\text { stxl, eae, ehly: } 1 \text { (100) } \\
\text { stxl: } 2 \text { (100); stx2: } 1 \text { (50); eaeA: } 2 \text { (100); stxl, eaeA: } 1 \text { (50); stx2, eaeA: } 1 \text { (50); stxl, stx2, eaeA: } 1 \text { (50) }\end{array}$ \\
\hline Ice-cream (2) & $\begin{array}{l}\text { Non detected } \\
\text { EHEC } \\
\text { AEEC } \\
\text { Total }\end{array}$ & $\begin{array}{l}- \\
1(50) \\
1(50) \\
2(100)\end{array}$ & $\begin{array}{l}\text { stxl, eae, ehly: } 1(100) \\
\text { stxl: } 1 \text { (100); stx2: } 1 \text { (100); eaeA: } 1 \text { (100); stxl, eaeA: } 1 \text { (100); stx2, eaeA: } 1 \text { (100); stxl, stx2, eaeA: } 1 \text { (100) } \\
\text { - }\end{array}$ \\
\hline Barbecue (5) & $\begin{array}{l}\text { Non detected } \\
\text { EHEC } \\
\text { AEEC } \\
\text { Total }\end{array}$ & $\begin{array}{l}1(33.33) \\
2(66.66) \\
3(60)\end{array}$ & $\begin{array}{l}\text { stxl, eae, ehly: } 1 \text { (100) } \\
\text { stxl: } 2 \text { (100); stx2: } 1 \text { (50); eaeA: } 2 \text { (100); stxl, eaeA: } 1 \text { (50); stx2, eaeA: } 1 \text { (50); stxl, stx2, eaeA: } 1 \text { (50) } \\
\text { - }\end{array}$ \\
\hline Spices (3) & $\begin{array}{l}\text { Non detected } \\
\text { EHEC } \\
\text { AEEC } \\
\text { Total }\end{array}$ & $\begin{array}{l}- \\
1(50) \\
1(50) \\
2(66.66)\end{array}$ & $\begin{array}{l}\text { stxl, eae, ehly: } 1(100) \\
\text { stxl: } 1 \text { (100); stx2: } 1 \text { (100); eaeA: } 1 \text { (100); stxl, eaeA: } 1 \text { (100); stx2, eaeA: } 1 \text { (100); stxl, stx2, eaeA: } 1 \text { (100) } \\
\text { - }\end{array}$ \\
\hline Total (26) & $\begin{array}{l}\text { Non detected } \\
\text { EHEC } \\
\text { AEEC } \\
\text { Total }\end{array}$ & $\begin{array}{l}3(15.78) \\
7(36.84) \\
10(52.63) \\
19(73.07)\end{array}$ & $\begin{array}{l}\text { stxl, eae, ehly: } 7 \text { (100) } \\
\text { stxl: } 10 \text { (100); stx2: } 6 \text { (60); eaeA: } 10 \text { (100); stxl, eaeA: } 6 \text { (60); stx2, eaeA: } 6 \text { (60); stxl, stx2, eaeA: } 6 \text { (60) }\end{array}$ \\
\hline
\end{tabular}


produced in high temperature and therefore were free from any pathogenic bacteria. Barbecue is a meat-based Kebab produced by roasting of beef on the charcoal. This cooking style cause superficial roasting and the interior parts of the meat remains raw. This is the main reason for the high prevalence of STEC strains in this food product. Using from un-washed vegetables caused high prevalence of STEC strains in salad samples of our study.

Another part of our findings revealed the high prevalence of STEC virulence factors and especially stx 1 and eaeA. High presence of these factors in EHEC and AEEC subtypes showed their significant pathogenicity for people who consumed from these foods. Simultaneous presence of stx 1 and eaeA and stx 2 and eaeA virulence factors in some strains of $E$. coli of ready to eat foods represented an important public health issue regarding the consumption of ready to eat foods.

Several investigations have been conducted in this field al-around the world. ${ }^{13-16}$ Momtaz et al. ${ }^{13}$ reported that the prevalence of $E$. coli strains among meat samples was $29.02 \%$. They showed a considerable prevalence of $E$. coli in sheep meat $(35.45 \%)$. The results of their investigation revealed the higher prevalence of AEEC than EHEC subtypes and also considerable distribution of $s t x 1$ and eaeA virulence factors. Hemmatinezhad et al. ${ }^{14}$ reported that the prevalence of $E$. coli in various types of foods had a range of $9-28 \%$. They showed that the prevalence of stxl gene in the AEEC strains was 100\% and EHEC-positive strains harbored all three stx 1, eaeA and ehly genes. Ranjbar et al. ${ }^{15}$ showed that the prevalence of $E$. coli in various types of raw and cooked food samples was $6.72 \%$. They showed that prevalence of $E$. coli in raw meat, raw chicken and raw fish, cooked meat, cooked chicken, cooked fish and soup samples were $20 \%, 16.66 \%, 1.42 \%, 6 \%$, $3 \%, 2.72 \%$ and $5 \%$, respectively. They showed that prevalence of EHEC and AEEC subtypes in raw meat and chicken, cooked meat, chicken and fish and soup samples were $16.66 \%$ and $50 \%, 20 \%$ and $60 \%, 25 \%$ and $50 \%, 0 \%$ and $33.33 \%, 0 \%$ and $50 \%$ and $33.33 \%$ and $66.66 \%$, respectively. Their findings showed that EHEC strains harbored all three stx 1 , eaeA and ehly genes together (100\%), while AEEC strains harbored different percent of these genes. Shayegh et al. ${ }^{16}$ reported that 22 out of 200 samples studied (11\%) were positive for E. coli. They represented that $54.54 \%$ of $E$. coli isolates were STEC. In addition to our results and also finding of Momtaz et al. ${ }^{13}$ Hemmatinezhad et al. ${ }^{14}$ and Ranjbar et al., ${ }^{15}$ simultaneous presences of stx 1 , stx2, eaeA and ehly virulence factors have also been reported by Franz et al. ${ }^{17}$ JayRussell et al. ${ }^{18}$ and Kabiru et al. ${ }^{19}$

\section{Conclusions}

In conclusions, we identified a large numbers of virulence factors in the STEC strains isolated from ready to eat foods. High contamination rate of salad, candy and barbecue and considerable prevalence of stx 1 and eaeA virulence factors were the most commonly determined properties of STEC strains of ready to eat foods. Presence of EHEC strains in majority of food samples represents inadequacy of time and temperature used for cooking of food samples and also transmission of pathogenic agents from animal sources to them. It seems that there were no firm managements on the principles of food hygiene in Iranian ready to eat foods. However, further studies are required to determine the distribution of serotypes and antibiotic resistance properties of STEC strains and also their sequencing to found important epidemiological data about the presence of STEC strains in ready to eat foods.

\section{References}

1. Isara AR, Isah EC. Knowledge and practice of food hygiene and safety among food handlers in fast food restaurants in Benin City, Edo State. Niger Postgrad Med J 2009;16:207-12.

2. Momtaz H, Farzan R, Rahimi E, et al. Molecular characterization of Shiga toxin-producing Escherichia coli isolated from ruminant and donkey raw milk samples and traditional dairy products in Iran. Sci World J 2012;2012:231342.

3. Kabli SAA, Hadhoud AEDA, Nabih Baeshen M. An epidemiological survey of extended-spectrum $\beta$-lactamases producing bacteria genotypes and the evaluation of the antimicrobial effect of Rhazya stricta leaf. Microbiol Res 2012;3.

4. Bakhtiari R, Mehrabadi JF, Agamirzaei $\mathrm{HM}$, et al. Evaluation of extended spectrum beta lactamase enzymes prevalence in clinical isolates of Escherichia coli. Microbiol Res 2011;2.

5. Rasheed MU, Thajuddin N, Ahamed P, et al. Antimicrobial drug resistance in strains of Escherichia coli isolated from food sources. Rev Inst Med Trop Sao Paulo 2014;56:341-6.

6. Dehkordi FS, Yazdani F, Mozafari J, Valizadeh Y. Virulence factors, serogroups and antimicrobial resistance properties of Escherichia coli strains in fermented dairy products. BMC Res Note 2014;7:1.

7. Momtaz H, Karimian A, Madani M, et al. Uropathogenic Escherichia coli in Iran: serogroup distributions, virulence factors and antimicrobial resistance properties. Ann Clin Microbiol Antimicrob 2013;12:1.

8. Momtaz H, Dehkordi FS, Hosseini MJ, et al. Serogroups, virulence genes and antibiotic resistance in Shiga toxin-producing Escherichia coli isolated from diarrheic and non-diarrheic pediatric patients in Iran. Gut Pathog 2013;5:1.

9. Woo PC, Cheung EY, Leung KW, Yuen KY. Identification by $16 \mathrm{~S}$ ribosomal RNA gene sequencing of an Enterobacteriaceae species with ambiguous biochemical profile from a renal transplant recipient. Diagn Microbiol Infect Dis 2001;39:85-93.

10. Hussein HS, Bollinger LM. Prevalence of Shiga toxin-producing Escherichia coli in beef cattle. J Food Prot 2005;68: 2224-41.

11. Llorente P, Barnech L, Irino K, et al. A. Characterization of shiga toxin-producing Escherichia coli isolated from ground beef collected in different socioeconomic strata markets in Buenos Aires, Argentina. Biomed Res Int 2014; 2014:795104.

12. Shamsul BMT, Tukur Adamu M, Mohd Desa MN, et al. Prevalence of Escherichia Coli O157:H7 and Enterobacteriaceae on hands of workers in halal cattle abattoirs in peninsular Malaysia. Malays J Med Sci 2016;23: 65-71.

13. Momtaz H, Dehkordi FS, Rahimi E, et al. Incidence of Shiga toxin-producing Escherichia coli serogroups in ruminant's meat. Meat Sci 2013;95:381-8.

14. Hemmatinezhad B, Khamesipour F, Mohammadi M, et al. Microbiological investigation of $\mathrm{O}$-serogroups, virulence factors and antimicrobial resistance properties of shiga toxin-producing Escherichia Coli isolated from Ostrich, Turkey and Quail Meats. J Food Safety 2015;35:491-500.

15. Ranjbar R, Masoudimanesh M, Safarpoor Dehkordi F, et al. Shiga (Vero)-toxin producing Escherichia coli isolated from the hospital foods; virulence factors, o-serogroups and antimicrobial resistance properties. Antimicrob Res Infect Control 2017; $6: 4$.

16. Shayegh J. Prevalence of Escherichia coli O157:H7 in bovine feces in North West of Iran. Microbiol Res 
2017;8:6587.

17. Franz E, Klerks MM, De Vos OJ, et al. Prevalence of Shiga toxin-producing Escherichia coli stx1, stx2, eaeA, and rfbE genes and survival of E. coli O157: $\mathrm{H} 7$ in manure from organic and lowinput conventional dairy farms. Appl Environ Microbiol 2007;73:2180-90.
18. Jay-Russell MT, Hake AF, Bengson Y, et al. Prevalence and characterization of Escherichia coli and Salmonella strains isolated from stray dog and coyote feces in a major leafy greens production region at the United States-Mexico border. Plos One 2014;9:e113433.

19. Kabiru LM, Bello M, Kabir J, et al.
Detection of pathogenic Escherichia coli in samples collected at an Abattoir in Zaria, Nigeria and at different points in the surrounding environment. Int J Environ Res Publ Health 2015;12:67991. 